\title{
Ro - Ro Ferry safety: do the passengers aware the safety aspects during voyage?
}

\author{
Antoni Arif Priadi ${ }^{1, *}$, Lili Purnama Sita ${ }^{1}$, Vidia Selasdini ${ }^{1}$, Retno Sawitri Wulandari ${ }^{1}$ \\ ${ }^{1}$ Sekolah Tinggi Ilmu Pelayaran Jakarta, Jakarta, Indonesia
}

\begin{abstract}
Beginning of 2017, the society had been shocked by the ship accident which occurred at Kepulauan Seribu Jakarta which had caused the death of dozens passengers on board who died are likely to be caused by panic and do not know what should to do. The objective of research is to gather the information related to the safety knowledge of Ro-Ro ferry passengers during voyage at sea. The gap analysis method is applied to find the differences between perception and expectation of Ro-Ro ferry passenger towards safety aspects. The result indicated that there is gap for all variables which can be categorized into three groups. The results give the important point for developing further approach to avoid similar incident in the. Further research on the detail approach need to be carried out which focus on the effective way in increasing the safety awareness of Ro- Ro ferry passenger.
\end{abstract}

\section{Introduction}

\subsection{Background of the research}

The first ship incident happened in Januari 2017, the KM Zahro Express ferry. She was carried over 200 passengers, caught fire during her way to Tidung Island, Thousand Islands. The National Disaster Mitigation Agency (BNPB) reported 23 passengers were killed while 17 people suffered injuries. It further said 194 passengers survived the incident while 17 others were reported still missing [1]. The Police already stated that the Master of KM Zahro Express as a suspect being considered to meet two elements of evidence, such as the ship's safety equipment and the responsibility on safety, security and the property of vessel, seafarer \& cargo. The second vessel is KM. Mutiara Sentosa I which also caught fire in Masalembu Island in May 2017, caused 5 peoples died [2]. Result of the investigation from the KNKT said that the fire came from the lower deck from the truck. There were also differences from the numbers on the manifest to the number of peoples evacuated [3]. The similar accident occurred in April 2014 at South Korean vessel. The Sewol carried 476 persons when it took a capsized off the southwestern island of Jindo [4]. The victims is 304 loss of lives and of those, 250 were

* Corresponding author: puket1.stip.jkt@,gmail.com 
student. The question raised in these incidents is why there are a lot of passengers missing? Are they aware of the safety aspect on board the ship? Do they have sufficient knowledge on how to abandon the ship? Those questions lead to this research aimed to analyze the safety knowledge of the passenger during voyage by using gap analysis.

\subsection{Previous research}

Safety is a human perceived quality that determines to what extend the management, engineering and operation of a system is free of danger to life, property and the environment [5]. Another definition, safety is "the state of not being exposed to danger, a protective device (as on a weapon) to prevent accidental operation" [6]. Based on this definition, safety is really related to the perception of human towards a thing. For example, related to the voyage using a ship, the human will behave a safety matter regarding their perception towards safety on board ship.

A research related safety perception showed that eventhough the overall safety knowledge of the passengers can be considered good, but there is some differences between groups of passengers [7]. Younger passengers and passengers on shorter trips generally have less safety knowledge than older passengers and passengers on longer trips. Their study also addressed the effects of two different formats of presenting safety relevant information on passengers' perception of trust, safety and risk on board. Another research identified five safety perception themes. [8]. The results specify that passengers perceive safety through the architecture of the passenger ship, the life-saving appliances, communication, emotions and other people. The article gives to safety research on passenger ship design, where human perceptions and reactions to the surrounding environment significantly affect behavior.

\subsection{Research methodology}

The methodology applied for this research is gap analysis. The gap analysis is the comparison of the perception to the expectation on safety related issues. Gap analysis consists of several steps. The first step is the data collection method, followed by validity test, reliability test and at the end the gap analysis is applied.

Gap analysis is used to determine the steps which is need to be taken for further movement from recently condition to the expected condition in the future. The gap analysis is also a means of ccomparasion between actual performance and future performance. This gap analysis also identifies the actions plan to achieve the future performance [9].

Sample of data collection was done through random sampling for the ship passenger who travelling from Port of Merak to Bakauheni. To decide the number of sample from the population, the table and guidance is employed. In general, the minimal number of sample for correlation research is 30 [10]. The primary data used in this research is obtained from survey with questionnaires distributed in June 2017.

Having primary data, the validity and reliability test are conducted. Validity test is used to measure validity of a questionnaire. A questionnaire is stated valid if the question of the questionnaire could explore things which will be measured by such 
questionnaire. The validity test is applied through the comparison of the calculated $r$ with $\mathrm{r}$ from table. If the calculated $\mathrm{r}$ for each $\mathrm{r}$ questionnaire items values a positive and has higher values then it could be stated that the questionnaire items is valid [11].

The reliability is the instrument to measure a questionnaire which is an indicator of variable [12]. High reliability measurement means that the measurement is able to provide reliable result. A questionnaire items is said to be reliable if the answer of respondent to the questionnaire is consistent. To determine the coefficient of reliability, the Cronbach's Alpha is applied. If the value of Cronbach's Alpha is more than 0.60, it means that the variable is reliable. For this purpose, the SPSS version 18 is used.

To do the gap analysis between perception and expectation, the difference average values of each perception and expectation items is calculate which expectation values perception values [13].

$$
Q=P(\text { Perception })-E(\text { Expectation })
$$

The safety matters for this research consists of 16 variables. The variables name is started from passenger ticket checking (V1), passengers luggage checking (V2), passengers room direction (V3), muster station direction (V4), location of muster station (V5), Alarm sign (V6), Public addressor volume (V7), abandon instruction (V8), information for evacuation (V9), Crew identity (V10), Lifejackets location (V11), Lifejackets instruction (V12), Instruction to use lifejackets by crew (V13), Firefighting apparatus location identification (V14), Firefighting apparatus instruction (V15), and Instruction to use firefighting instruction (V16).

\section{Discussion}

\subsection{Port of Merak}

The Port of Merak is a seaport located in front of the Pulau Merak Besar sub district of Cilegon, Banten, on the Nnorthwestern tip of Java, Indonesia. The port is a key transport link between Java and Sumatra and is a major service provider for the heavy passenger and commercial ferry traffic from Merak to Bakauheni across the Sunda Strait on the Ssouthern tip of Sumatra. The overview of Port of Merak is illustrated in figure 1. 


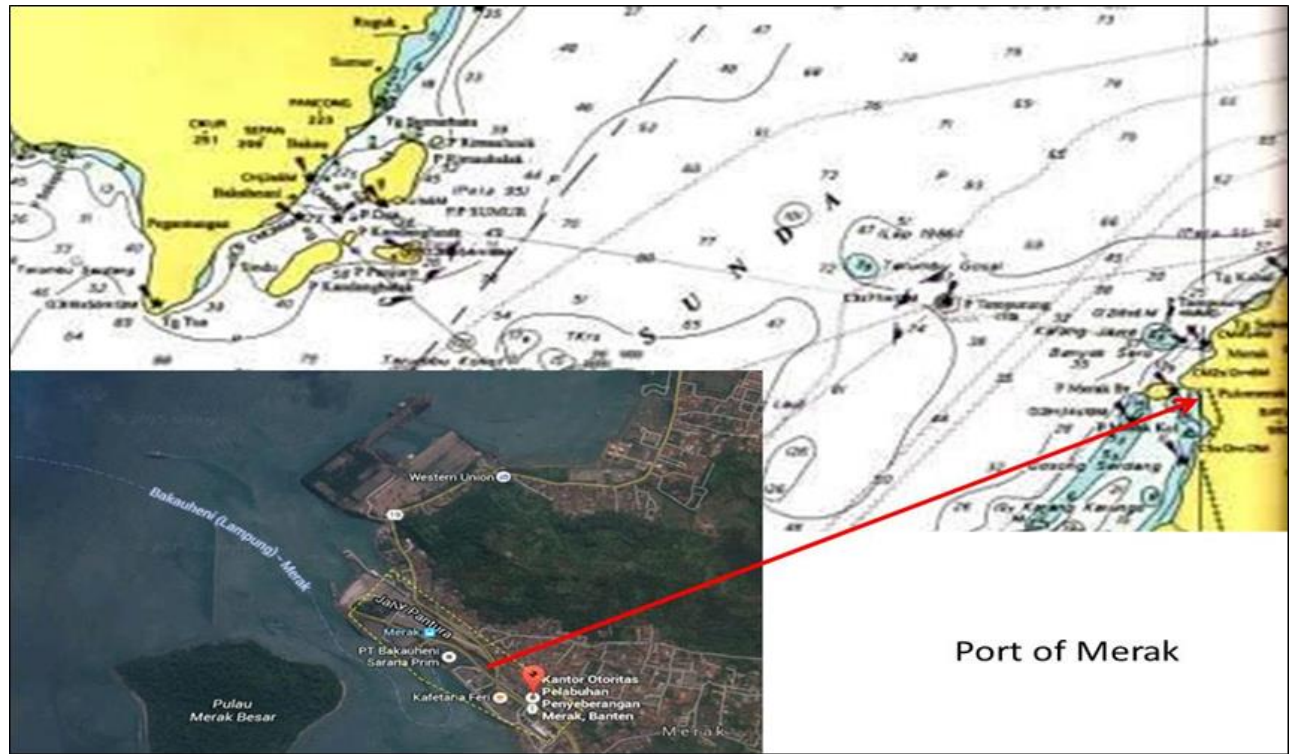

Fig. 1. Overview of Merak Port

Port of Merak consists of five jetty. The nearest one to the entrance gate is jetty no. 1. The furthest jetty is located at jetty no. 5. The layout of Port of Merak is illustrated in figure 2.

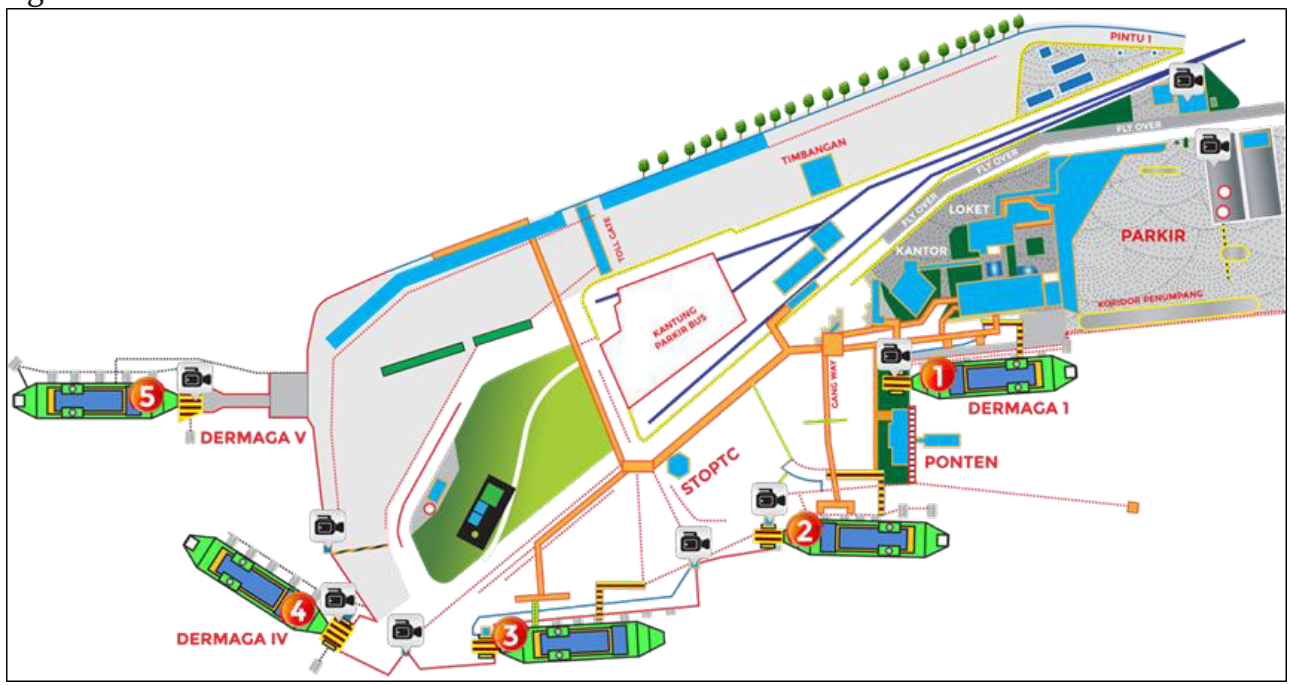

Fig. 2. Layout of jetty at Merak Port

Source :http://bestananda.blogspot.co.id/2015/07/pelabuhan-merak-banten.html

Growth in demand for ferry services has been rapid in recent years. For instance during holiday such as Eid Fitr 2017, there are more than 200 thousands passenger travelling by ship from Merak to Bakaheuni and vice versa. This number of passenger is counted for several days during Eid Fitr 2017. Additionally, more passengers travel together with their car or motorcycle. The detail of port production is figured out in table 1 . 
Table 1. Number of cargo during eid fitr 2017

\begin{tabular}{|c|l|c|}
\hline \multicolumn{3}{|c|}{$\begin{array}{c}\text { Review of Tranportation Production During Eid Fitr } \\
\text { Holiday for Merak Port, 2017 }\end{array}$} \\
\hline No & Type of Cargo & $\mathbf{2 0 1 7}$ \\
\hline 1 & Passanger & 256.638 \\
\hline 2 & Passenger with car & 1.180 .912 \\
\hline 3 & Motorcycle & 105.601 \\
\hline 4 & Cars & 186.182 \\
\hline 5 & Bus & 9.323 \\
\hline 6 & Truck & 27.724 \\
\hline
\end{tabular}

Source : modified from http://oppmerak.dephub.go.id/\#link

\subsection{Respondent profile}

The respondent profile includes the respondent age, education background, employment status and travelling number by ship. The total number of respondent is 115 passengers. For the respondent age, $66 \%$ of passengers have age less than 31 years old. The educational background, the 51 passenger graduated from senior high school and $33 \%$ graduated from higher education. Further, regarding the employment status, $60 \%$ of passenger worked for private sector and $14 \%$ worked as civil servant. To the last respondent profile, the travelling number on the same route, the $65 \%$ of passenger have previous experience between once and three times. For four times to six times, there are only $22 \%$ passengers accounted.

\subsection{References}

Based on the methodology, the first step of analysis is the validation of data. The validation of data consists of the perception data and expectation data. The result of Pearson Correlation is used to determine the validation of data. The result of validation test is figured out in table 2 . The 16 variables are valid for this research.

Table 1. The validation test result 


\begin{tabular}{|c|l|c|c|}
\hline No. & \multicolumn{1}{|c|}{ Variables } & Corr Perception & $\begin{array}{c}\text { Corr } \\
\text { Expectation }\end{array}$ \\
\hline 1 & Check ticket &, $539^{* *}$ &, $670^{* *}$ \\
\hline 2 & Check luggage &, $427^{* *}$ &, $655^{* *}$ \\
\hline 3 & Direction to passenger space &, $574^{* *}$ &, $669^{* *}$ \\
\hline 4 & Direction to muster &, $652^{* *}$ &, $686^{* *}$ \\
\hline 5 & Identification muster &, $626^{* *}$ &, $714^{* *}$ \\
\hline 6 & Identification muster &, $704^{* *}$ &, $767^{* *}$ \\
\hline 7 & Public addressor &, $464^{* *}$ &, $675^{* *}$ \\
\hline 8 & Emergency guidance &, $701^{* *}$ &, $767^{* *}$ \\
\hline 9 & Evacuation information &, $631^{* *}$ &, $736^{* *}$ \\
\hline 10 & Crew identity &, $704^{* *}$ &, $682^{* *}$ \\
\hline 11 & Lifejacket location &, $761^{* *}$ &, $538^{* *}$ \\
\hline 12 & Lifejacket instruction &, $718^{* *}$ &, $722^{* *}$ \\
\hline 13 & Crew inform use lifejacket &, $658^{* *}$ &, $700^{* *}$ \\
\hline 14 & Fire fighting app &, $571^{* *}$ &, $643^{* *}$ \\
\hline 15 & Fire fighting instruction &, $592^{* *}$ &, $724^{* *}$ \\
\hline 16 & Crew inform use ff app &, $696^{* *}$ &, $637^{* *}$ \\
\hline
\end{tabular}

The next test is the reliability test. The first test is applied for the perception of respondent as the result is shown in table 3. Based on the value of Cronbach's Alpha which is 0.896 , it means the respondent perception is reliable for this research. Number of respondent are 115 and there are 16 questions in the questionnare, total number data collected are 1.840 to analyze. This quistionarre is arranged to identify the requirements of passenger's safety on board.

Table 2. Reliability test for perception

\begin{tabular}{|c|c|r|}
\hline $\begin{array}{c}\text { Cronbach's } \\
\text { Apha }\end{array}$ & $\begin{array}{c}\text { Cronbach's } \\
\text { Apha Based } \\
\text { on } \\
\text { Standardized } \\
\text { Items }\end{array}$ & N of Items \\
\hline 896 &, 900 & 16 \\
\hline
\end{tabular}

The similar value is obtained for expectation of respondent as it is shown in table 4 . The value of Cronbach's Alpha is 0.926 . Therefore, it could be stated that the data is reliable for this research.

Table 3 Reliability test for expectation 


\begin{tabular}{|c|c|r|}
\hline $\begin{array}{c}\text { Cronbach's } \\
\text { Alpha }\end{array}$ & $\begin{array}{c}\text { Cronbach's } \\
\text { Apha Based } \\
\text { on } \\
\text { Standardized } \\
\text { Items }\end{array}$ & N of Items \\
\hline 926 &, 927 & 16 \\
\hline
\end{tabular}

The The gap analysis result is illustrated in figure 3. Three areas of variable is identified having highest value such as the checked ticket before entering ship (V1), checked baggage before entering ship(V2) and evacuation information (V9). The passenger expects that luggage/baggage need to be checked for safety reason as well as passenger ticket. The evacuation information to the passenger is also a matter that the passenger expects have right information if there is signal to head muster station.

The second group consists of five areas which are fire-fighting apparatus instruction (V15), Crew identity (V10), Lifejackets location (V11), Instruction to use lifejackets by crew (V13), and muster station direction (V4). The third group has lower value of gap which are lifejackets instruction (V12), instruction to use fire-fighting instruction (V16), passengers room direction (V3), location of muster station (V5), alarm sign (V6), public-addressor volume (V7), and fire-fighting apparatus location identification (V14). For the third group, most of passenger aware with it, yet some passenger feel need for more information.

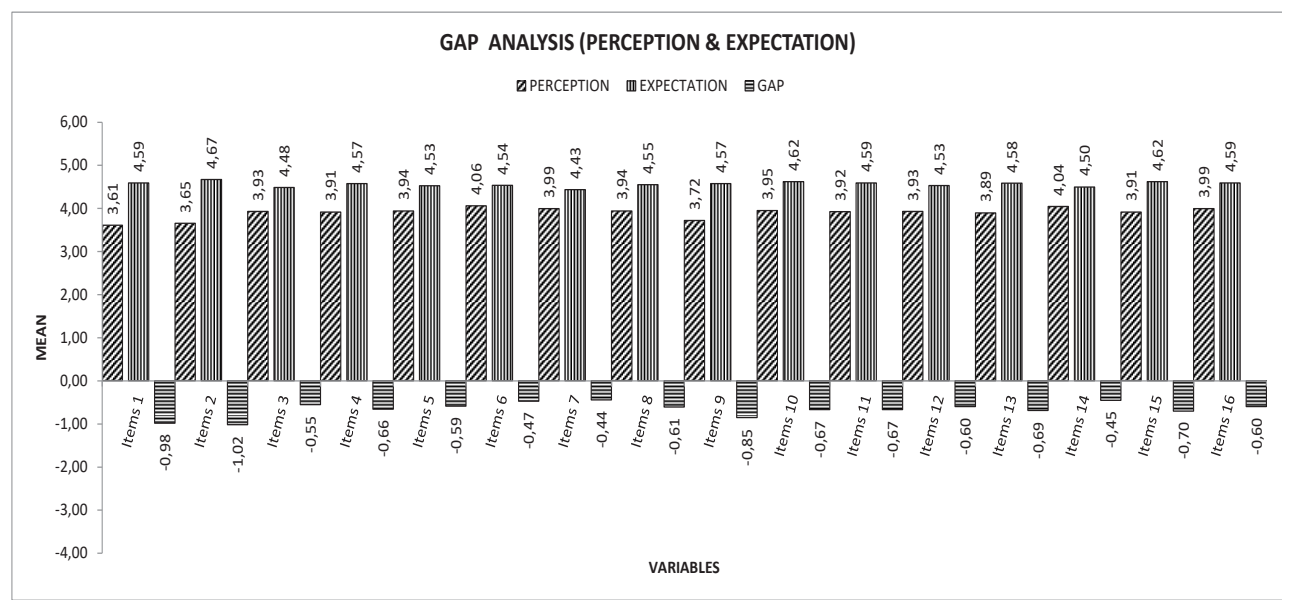

Fig. 1 Gap Analysis Result

\section{Conclusion}

Refer to the discussion above, the overall result of the gap analysis shows that for the safety related matter, there is gap for all variables. It means that there is need to give the more information to the passenger as actually they have high expectation to the safety related matter during voyage at Ro- Ro ferry. It could be stated that the passenger have high awareness level which is shown through the expectation level. It also could be stated that method to give more information of related safety need to be carried out not 
only by crew but also by the port authority through brochure, ticket, etc. While the crew member need to aware this matter to focus more on the safety knowledge of the passengers before departing port. The risk of accident of the ship during voyage is always there. When this situation occurs, the readiness of the passengers to counter the situation really depends on the passenger's knowledge of the safety related matter. Otherwise, the passengers will not know what to do and later just jump to the sea. The shipping companies also need to encourage and to establish the procedure of safety related matter to the passengers through the social engineering for instance, the life jacket is available at the passenger's seat and should be put on or the passengers is not allowed to sit. The shipping companies need to give more efforts to inform the passenger about emergency guidance, evacuation information and lifejacket instruction as the result of analysis. Further research on the different perception of safety by education parameter need to be carried out for finding relationship between safety related matter and education level.

\section{References}

1. The Jakarta Post. "ministry-to-standardize-thousand-islands-service-after-zahroexpress-incident." thejakartapost.com. Retrieved June 10, 2017 (www.thejakartapost.com/news/2017/01/02/ministry-to-standardize-thousand-islandsservice-after-zahro-express-incident.html). (2017)

2. CNN Indonesia. "penumpang-km-mutiara-sentosa-1-sudah-dievkuasi." www.cnnindonesia.com. Retrieved June 10, 2017 (www.cnnindonesia.com/nasional/ 20170520094349-20-216076/penumpang-km-mutiara-sentosa-1-sudah-dievkuasi/ ). (2017)

3. Nasional.tempo.co. "www.nasional.tempo.co." km-mutiara-sentosa-i-terbakar-knktselidiki-truck-sumber-api. Retrieved June 10, 2017 (www.nasional.tempo.co $/ \mathrm{read} /$ news $/ 2017 / 05 / 21 / 058877324 / \mathrm{km}$-mutiara-sentosa-i-terbakar-knkt-selidiki-trucksumber-api). (2017)

4. Dailymail.co.uk. "http://www.dailymail.co.uk." Eerie-pictures-untouched-classroom belonging-students-teachers-killed-Sewol-ferry-disaster-South-Korea. Retrieved June 10, 2017 (http://www.dailymail.co.uk/news/article-3605976/Eerie-pictures-untouchedclassroom-belonging-students-teachers-killed-Sewol-ferry-disaster-South-Korea.html). (2016)

5. Kuo, C. Safety Management and Its Maritime Application. London: The Nautical Institute. (2007)

6. Merriam-webster.com. n.d. "safety." www.merriam-webster.com/thesaurus. Retrieved June 10, (http://www.merriam-webster.com/thesaurus/safety). (2017)

7. Hystad, S.W., Oyeniyi S.O., and Jarle, E. Safe travel: Passenger assessment of trust and safety during seafaring. Transportation Research Part F 38:29-36. (2016)

8. Ahola, Markus, Pekka, M., Pentti, K., and Juhani, P. Perceiving safety in passenger ships - User studies in an authentic environment. Safety Science 70 (2014) 70 :222232. (2014)

9. Suroto, A. Gap Analysis. http://sis.binus.ac.id. Retrieved June 10, 2017 (http://sis.binus.ac.id/2015/07/28/gap-analysis-analisa-kesenjangan/). (2015)

10. Sekaran, U. Metodologi Penelitian untuk Bisnis. Jakarta: Salemba Empat. (2006) 
11. Sujarweni, V. W. SPSS Untuk Penelitian. Yogyakarta: Pustaka Baru. (2015)

12. Sunyoto, D. Analisis Regresi dan Uji Hipotesis. Yogyakarta: Media Pressindo. (2009)

13. Wijaya, T. Manajemen Kualitas Jasa. Jakarta: PT. Indeks. (2011) 